\title{
On the Internal Communications of India
}

\section{J. Bourne Esq., C.E.}

To cite this article: J. Bourne Esq., C.E. (1858) On the Internal Communications of India, Royal United Services Institution. Journal, 2:6, 207-223, DOI: 10.1080/03071845809415908

To link to this article: http://dx.doi.org/10.1080/03071845809415908

$$
\text { 曲 Published online: } 11 \text { Sep } 2009 .
$$

Submit your article to this journal $\pi$

山ll Article views: 3

Q View related articles $\longleftarrow$ 
Rexwolps. International Colle. Nautical Telegrall for the use of Men of War and Merchant Vesscls. 8vo, London, 1857.

Code International, Télégraphie Nautique, 8vo. Paris, 1857.

Improvements in Naval Architecture by Oliver Lang, Esq., Master Shipwright, Woolwich, 8ro. 1853.

A Summary of Facts drawn from the Records of the Society.

II. R. II. The Prince Consort. Council of the Royal Lilevary Funt.

MITSEuM.

Sectional Model of Penn's Trunk Engine as uscd in H.M. Steam-Ships.

E. Jeliyll, Esq. late Gren. Gds.

Bundles of Crossbow Bolts and Arrows obtained in Bohemia.

J. C. Robinson, Esq. Science and Art Department, Fensingtor.

A Cocked Hat that belonged to the late Duke of Wellington, and worn by him in the year 1815 .

A pair of Gloves worn by him at a Review in Iyde Park in 1846.

Ribbon of the Garter worn by him in 1845 .

Guznee Medal.

Punniar Star.

Sir sizlall Scoll, Dart.

Impression upon White Satin taken from the actual Plate on the State Coffin crelosing the Duke of Wellington's remains.

D. Tupper, Esq. Lord Chamberlain's Office.

A Quintant, an instrument that belonged to, and was used frequently by, the Late Lt.-Gen. Sir Charles J. Napier, K.C.B.

Col. MrcIrurdo, C.B. Commandant Military Train.

A Model of Clifford's new method of unlashing, lowering, and disengaging ships' boats, as adopted by the Lords Commissioners of the Admiralty.

11r. Charles Cliford.

\section{ON THE INTERNAL COMIIUNICATIONS OF INDIA.*}

By J. Bounse, Esq., C.E.

IN offering some remarks before this Institution on the internal communications of India, I cannot but be sensible that there are many gentlemen present here to-night who possess a more intimate and a more extended acquaintance with India than I can pretend to, and who would be better qualified for doing justice to such a subject. I hope we shall have the benefit of their criticisms after this paper has been read, for, if there is any material error in the

* On account of the importanco of the subject, it has been thought advisable to print this paper out of its ordinary course. 
views I shall set before you, it is desirable that such error should be pointed out; whereas if, on the contrary, it should appear to you that the doctrines I advocate are rensonable and sound, it will be a public adrantage that they go forth to the world backed by the authority of your acquiescence.

It is now thirteen years since $I$ first turned my attention to the subject of the internal communications of India. At that time Sir Macdonald Stephenson had just returned from India to state the measures necessary to initiate the East Indian Railway, and the data he brought home with him he placed in my hands to arrange. and disentangle, with the view of enabling an approximate estimate to be formed of the commercial prospects of the undertaking. At this time the nation was entering the whirl of the railway mania. All modest ideas of thrift and economy in railway matters were given to the winds, and the dominion of common sense was superseded by the empire of magnificent ideas. It is not to be supposed that the Indian railways should escape the influence of the prevailing epidemic, and an expensive system of railways for India was then inaugurated, which, though it subsequently received some rectification, perpetuates its evils to the present day. The result of iny investigations at this time rent to show that Indian railways would not pay well unless they were constructed in a very econoinical manner; and I recommended that, instead of the expensive double lines then proposed for execution, single lines of the cheapest possible construction consistent with efficiency should be made, short portions adjacent to important termini being constructed with a double track to accommodate the more frequent trains there required. The Railway Company did not at this time adopt my recommendation; nevertheless, in 1847 , they despatched me to India in connexion with the undertaking. Up to this period I had given no attention to the general subject of the internal communications of India, but I had merely been called upon to consider in what way a railway could be established in that country with the best prospect of success. Of the existing canals and roads, or of thicir action in developing the resources of the country, I knew as little as most Englishmen whose attention has not been specially directed to the East, while of the rivers all I knew was that they 
were reported, by reason of their shallowness, to be incapable of navigation by stcam in an effective manner.

On my arrival in India, I had occasion to proceed from Calcutta to Benares anil Mirzapore by the Grand Trunk Road. The railway, it was proposed, should pass through the same tract of country. as the road, and would be nearly parallel to it for its entire length. The road was carried on an embankment to preserve it from the inundations. Except in one place, for a distance of six miles, it was nearly a dead level. With the exception of three or four rivers, it was bridged throughout the 450 miles I traversed. The bridges and the embankments had been tested with reference to the inundations, and had become consolidated by time. The road was so necdlessly broad that only a narrow portion in the centre of it was uised for traffic, and a considerable width on each side was covered with vegetation, which, but for constant uprooting, would have. grown up into jungle. I proposed that the unused part of the road should be employed to lay down the rails upon, whereby the whole expense of the railwaty works would have been saved, an impervious fence of saul branches, such as is used in the jungle to preserve cottages from the attacks of wild beasts being used to separate effectually the road and the railway. If this had been done at the. time I proposed it, the railway connecting Calcutta with the north-. west provinces could easily have been opened in 1850. The Railway Company however declined to accede to this recommendation, for what reason I do not know. The railway collapse came. -tho undertaking was put into abeyance, as the capital necessary. to carry it out on the more expensive plans could not then be. obtained, and the railway connecting Calcutta with the north-west. provinces is. not completed yet, nor is it likely to be completed, I suppose, for some years.

In returning from Mirzapore to Calcutta, I proceeded by a steamvessel down the Ganges, and I here discoverel that the difficulty of navigating that river was attributable not so much to the physical defects of the river itself, as to the unsuitable character of the vesscls with which the navigation was performed. The vessel I cnbarked in drew too much water, and was therefore constantly getting aground upon sand-bauks and shallows. At the same time, 
it carried too little cargo, and when the vessel did gronnd, there was no efficient means of getting it afloat again. Such singular maladaptation of the means to the end was sufficient to revolt any mechanic; and in England or America it could not have existed for a day undiscovered or meorrected. But in India there are ferr mechanics, and the owners of stcam-vessels there have heretofore thought that, if they imported an English or American river-steamer, they accomplished all that was possible for the development of the navigation of the Indian rivers. It is not to be supposed indeed that such persons should be capable of contriving a species of ressel which would be well suited for that peculiar navigation. But, as I did not labour under the same disability, I have ventured to devise a species of ressel which will I believe snpply the desideratum, and the peculiarities of which will be readily apprehended by a reference to the plate annexed.* This combination consists of a steamer and five barges; but the number of barges may be increased or diminished, as occasion requires. The bow of each barge is a convex semicircle; and the stern of ench barge, except the last one, is a concave semicircle, and each converity fits into the corresponding concavity, so that the steamer and train of barges virtually form one long flexible vessel, of which the constituent portions are so articulnted to one another by the circular joints as to permit lateral deflection, and, at the same time, to prevent the ends of the several barges from advancing nearer together or receding further apart than the distance at which they were originally set. At the central point, from which cach convex bow is swept, a strong iron post stands about two feet and a half above the deck, and a similar post stands in each thin end of cach concave stern. From cach of the two posts in the concave end two strong wooden beans or bars, called "draw bars," proceed to the central post, from which the adjacent convex bow is swept, and these draw bars, while permitting deflection round this central post, prevent the ends of the barges from rubbing or touching, and at the same time serve to draw the barges after the steamer when the engine is set in motion. Proper apparatus is applied for deflecting the several vessels rela-

* The Council are indebted to Mr. Coley, the editor of "The Illustrated Inventor," for the use of these engravings. 

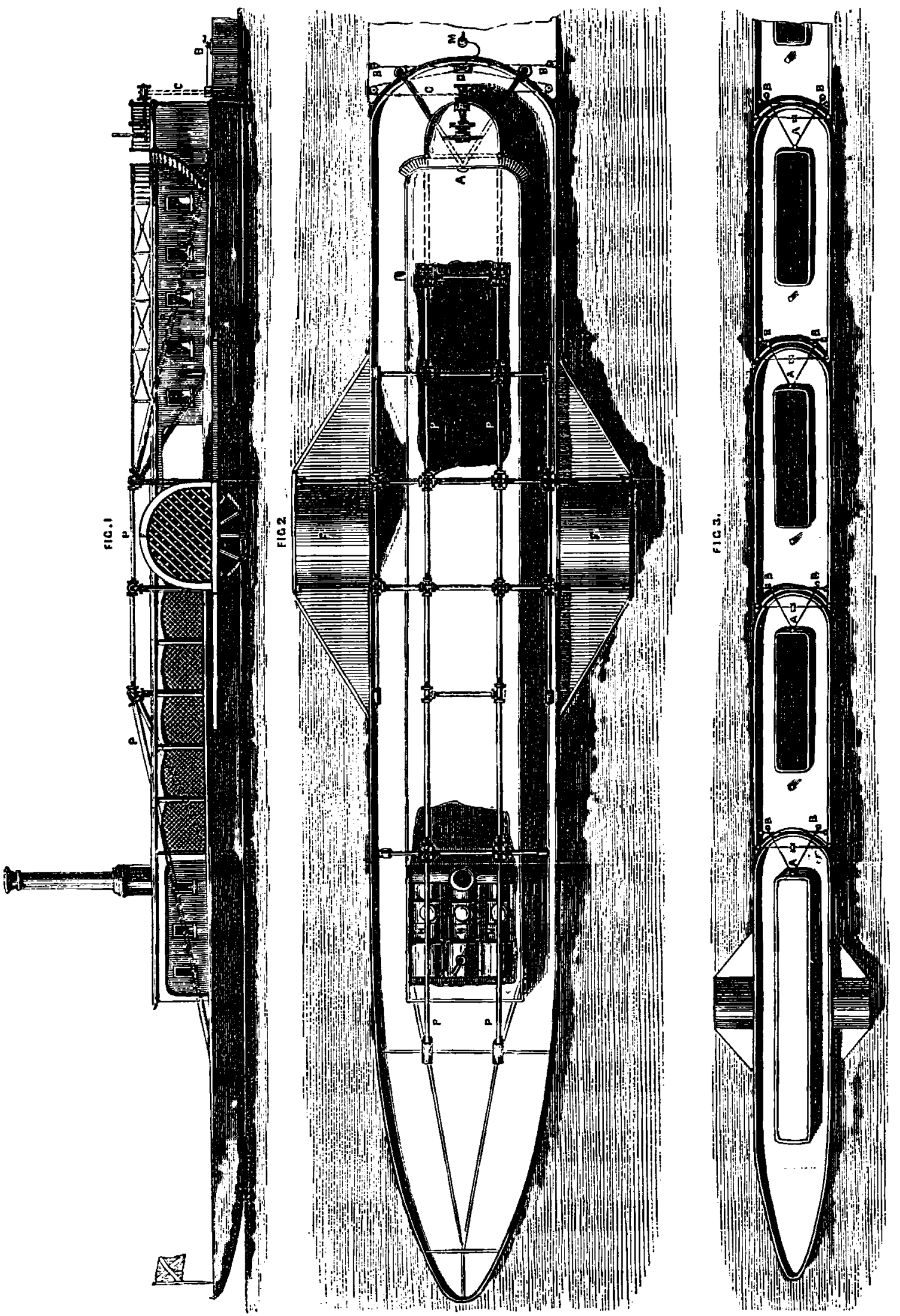

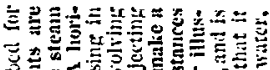

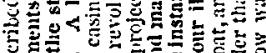

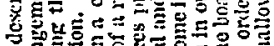

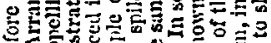

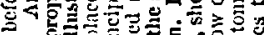

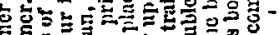

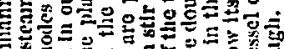

을

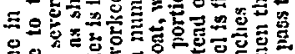

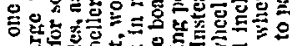

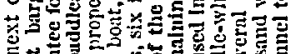

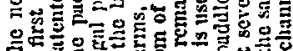

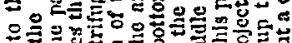

¿

2

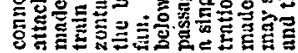

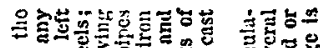

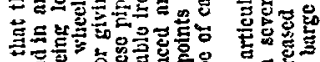

능

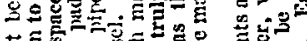

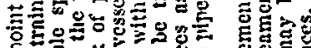

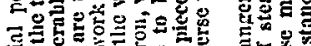

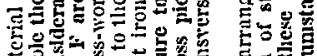

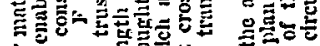

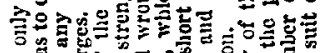

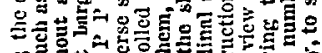

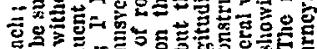

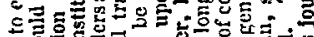

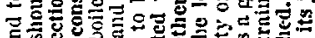

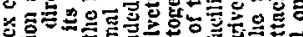
톨

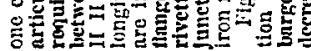

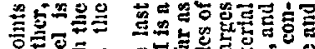

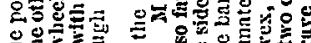

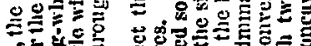

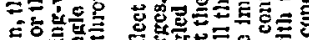

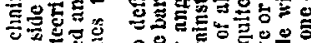

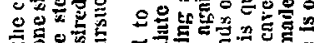

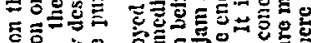

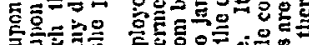

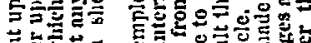

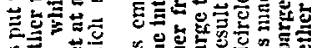

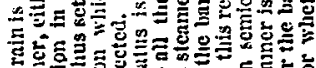

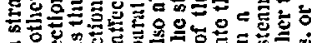

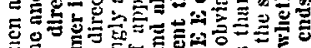

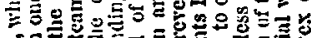

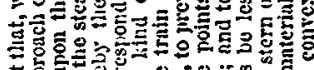

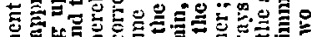

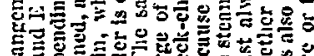

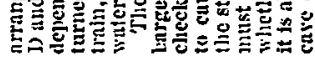

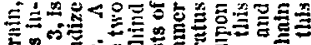

里地

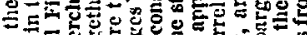

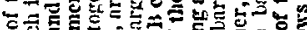

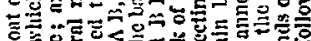

ड) 월

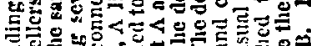

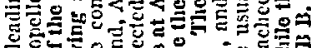

50

F政

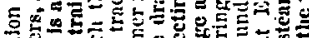

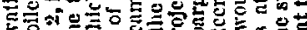

둥

멸

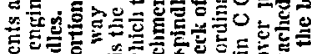

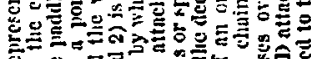

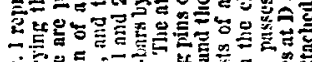

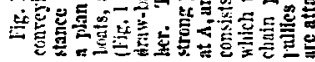


tivcly to one another, to any required extent; and by means of this apparatus, the train may be made to assume any required curve, just as the rertebra of a fish are bent by the muscles; and the train will thus pass without difficulty round sharp bends in a river, if such bends have to be encountered. The train is not provided with rudders, but it is guided solely by deflecting one or more barges of the train to the necessary extent. Every one knows that a ressel steers wildly when she gets into shallow water. The cause of this irregular nction is of easy perception, and the usual and natural expedient for counteracting it is the application of a rudder of colossal dimensions. It is impossible however, when the water comes to be very shallow, to get a rudder of the ordinary kind of sufficient length introduccd, and I meet the difficulty by maling the last barge of the train a floating rudder. I also make the steamer or first vessel of the truin a floating bow-rudder. If the intermediate barges of the train be kept rigid, the train will virtually be a resscl with an enormous floating rudder at each end. These great rudders require just the same exertion of manual labour to work them that would be necessary to work common rudders. For though these great rudders are harder to deflect they require to be deflected through a proportionately less angle, and by the application of an intermediate multiplying power of 6 to 1 a single man will manage these great rulders with the same ease that he would be able to manage a common rudder of the usual dimensions when fitted in the usual manner. As some persons were unable to understand how a train of barges of this kind could be guided without rudders, I thought it advisable, before procecding to build vessels upon this plan, to demonstrate the efficacy of the arrangement by a practical experiment. I therefore had a steamer and a train of barges fitted up upon the Clyde to set this point at rest. The result was to show that one man could accomplish the required deflection, and that by this expedient of stcering a far more efficient control was obtained over the morements of the vessels than any passible application of ordinary rudders could confer.

It will be obvious from the configuration of this train that it realizes the two most indispensable conditions in any expedient for the successful navigation of the Indian rivers-a large carrying 
power with a light draught of water. $\Lambda$, morcover, there is only one bow to clenve the water for the whole train, instead of a bow for each of its constituent barges, a high rate of speed is attainable with a moderate powrer. The draught of water of the trains which the Oriental Inland Steam Company is now about to establish upon the Indus will be about two feet when laden with scveral hundred tons of cargo. Each of these trains will be able to carry with case and comfort 1,000 soldiers, with their arms, accoutrements, and ammunition, and will afford about 12 square feet of deck-room for each man when thus employed. Such a train, from its light draught of water, will be very little liable to get aground in the river; but, if it should get aground, most effectual mechanical arrangements are provided for getting it alloat again without a moment's delay. It is clear that any vessel which runs upon a shoal can casily be dragged off again, provided an adequate force to pull her off is promptly applied; and the arrangements carried out in these trains for the attainment of this object are so powerful, that they would suffice under the worst circumstances for the accomplishment of the desired object. It is expected that the power of locomotion at a low rate of speed into deep water, even if the train should get aground, will be thus insured. With so small a draught of water as two feet the accident of grounding will seldom occur, and with the power of separating the train into a number of distinct barges, which may be dealt with separately and lightened into one another, the difficulty of dealing with the accident of grounding is infinitely less than when the problem is how to get afloat again a large and heavy vessel of the ordinary description. Nevertheless, it does not appear to me that the facilities arising from the practicability of lightening and separating the vessels are in themselves sufficient to obviate indefinite delays, and in my judgment every expedient for nnvigating the Indian rivers must be accounted defective which is not provided with some effectual means of immediately drawing the vessel off or over a shallow should she happen to ground upon it, seeing that however small the draught of water grounding will still sometimes take place. There is no difficnlty in making a provision of this kind for getting vessels off occasional shoals; and with this provision, and by 
employing resscls of a shallow draught, the Indian rivers may be navignted with as much ense and regularity as if there was not a shoal in thein from end to end.

All these things became plain to my mind from my observations in descending the Ganges, and, foreseeing that many years must clapse before the railways could be so far carried out as to render perecptible advantage in facilitating the communications of the country, and that even after they were made the rivers had still an important function to perform which no system of railways could ever accomplish, I endeavoured on my return from India in 1848 to induce the East India Company either to establish suitable ressels upon the Indian rivers themselves, or to give such aid to other parties as might be necessary for the accomplishment of this important improvement. Unfortunately the East India Company at that time declined to pursue either course, but last year, after the mutiny had shown what important purposes such vessels would have served, the East India Company consented to grant to the Oriental Inland Steam Company a ycarly subsidy to aid in the establishment of such vessels upon the Indus, and the two first trains, consisting of twelve vessels in all, have now been built. The demand for steam conveyance upon the Indus is of the most exigent claracter. That river is now becoming the great highway, not merely to the Punjaub and the north-rrest provinces of India, but to the whole of Central $A$ sia, and there are no commercial steam-vessels at present plying upon it. The government has several steamers running upon the river, but they are almost wholly occupied in carrying government stores and munitions of war; and the commercial wants of the country remain to the present moment unsatisfied, and even unrelieved. This field the Oriental Inland Steam Conspany proposes effectually to occupy, and all past experience of inland steam navigation in India has shown that when fairly managed it is highly profitable. The steam companies upon the Ganges habitually divide from 30 to 40 per cent. eren though the steam-ressels with which these large profits are earned are far less efficient, and carry much less cargo, than those which are now about to be introduced upon the Indus. By means of these vessels an unbrolsen communication may be maintained VYOL. İ. 
between the sea at Kurrachee and Ifydrabad, Moultan, Lahore, Ferozepore, Loodheana, Jhelum, and all the most important places of the Punjaub. An outlet will thus be afforded for the valuable productions of this extensive region, and an equally efficient inlet for British manufactures will be simultaneously afforded.

In any scheme for amending the internal communications of India I take it that there are tro main purposes to be subserved. The first is to promote the material development of the country in its commerce, in its agriculture, and in the social intercourse of its people. The second is to make the military occupation of the country more safe and easy to the ruling porrer. Whatever expedient of communication, therefore, best fulfils these objects should manifestly be the one which we should most strenuously urge into execution, provided the expense of the improvement is not so great as to place it beyond our retch. The expense, however, is an important part of the question, for it cannot be to the advantage of any nation to pursue commercial projects which are not of a remunerative character, and the military bencfits of an improved nethod of communication must be very eminent and very certain to justify any very heavy expenditure for their sole realisation. Now, all past experience shows that roads in India very soon return their expenses, and the same may be snid of canals of irrigation and navigation. Many roads are opened for gratuitous use, and there the benefit ie discemed by the improvement of the country and the local increase of the revenue, which ustally suflices to pay the rhole expense of the road in a short time. On some roads a small toll is imposed, the proceeds of which soon repay the expense of construction, and in general it may be stated that the introduction of roads is so profitable and grateful an improvement that it is highly desirable that it should be widely carried out. The same may be said of canals of navigation and irrigation. The profits of such works have nsually been very large: In Madras the arerage returns of all the irigation works established by the Government during the ten years preceding the time at which the return was made up was 691 per cegt. per annum upon the outlay, and it is clear that the advantage of such works to the country must have been very great when they were in such request as to yield so great a return on the cost of construc- 
tion. Steam navigation upon the Indian rivers has yielded a return of 30,40 , and $\mathrm{cren} 50$ per cent, though heretofore carried out in a comparatively inefficient manner: We may therefore conclude that stcam navigation is a proper thing to prosecute, since it could yield no sucli profits unless it were rendering important services to the conmunity. The railways established in India manifest no such farournble results. They are said to cxhibit a profit of from 3 to $6 \frac{1}{2}$ per cent., and so far as our present experience goes are not likely to carry any large quantity of first-class passengers or of goods, nor have they ip to the present time yielded any such profits as have been obtained from the navigation of rivers or from the establishment of works of irrigation. It is quite clear, from the comparative smallness of the profits, that the railways at present carried out in India are not the expedient of comminuication which the commercial wants of the country most require. That India wants is conveyanice for merchandise and passengers at a moderate specd and at the lowest possible cost, for as the country is of vast extent it is only when the cost of transport is very low that the agricultural produce of the interior ean reach the const at all. Now, nothing is better known than that of all possible modes of conveyance the cheapest is conveyance by water. If we suppose a railway to be carried from England to India it is quite clear that we should not receive the sugar, the cotton, the flax-seed, the rice, and the wool of India by that route; nor should we send to India by that route our coal, our iron, or our manufactures. Those articles, as will be apparent to every one, would still contintic to pass in ships round the Cape, notwithstanding the greater length of that royage, and for the simple reason that conveyance by water is cheaper than auy possible mode of land conveyauce. Seeing, then, that it is cheap conveyance at a moderate rate of speed that India chiefly requires, my opinion has long been that we shall most effectually and most promptly develope the resources of that country by pressing forward in an energetic manner the navigation of its great rivers by steam. That its rivers are navigable in an efficient manner with an appropriate species of vessel I have already cxplained, and my estimate is that there are at least 10,000 miles of rivers in India upon which such navigation should be at once established. 'That railways are most valuable aids 
to internal communication when constructed in an iuexpensive manner nnd carried in suitable directions, I equally maintain. But I hold it to be a waste of means to run a railway along the banks of a navigable river, when there are so many other works in India upon which the money consumed in the construction of such railway could be more usefully and profitably employed. Now the rivers exist. already; you have not to expend any money in making or repairing them, and $I$ think it is a most obvious indication, and one which will present itself to ercry unprejudiced mind, that the first thing to be done in amending the internal communications of India is to utilise the rivers as far as possible. There are about 4;000 miles of railway already sanctioned for construction in India, the estimated cost of

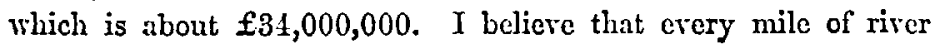
navigation will render more important benefits to India than every mile of railway, seeing that the river navigation more completely satisfies the wants of commerce in enabling large quantities of merchandise and large numbers of passengers to be carried through considerable distances at a small expense. If, however, we estimate the benefits of the rivers as only equal to those of an equal length of railway, it is easy to sce what an enormous advantage to the commerce of the country the opening up to steam navigation of 10,000 miles of rivers would afford.

But would the navigation of the rivers equally satisfy the military conditions of the problem? It seems to me that they would satisfy them better than the railways can do; for in any mutiny, such as that which has lately occurred, or in any case of revolt or rebellion, it is quite manifest that a railway could be more easily disabled than that a great river like the Indus or the Ganges could be stopped up. If some of the rails be lifted at intervals, or some of the viaducts be broken down, the railway will be disabled until these defects can be again repaired; but it would be very difficult to obstruct the navigation by steam of any of the great rivers by sinking boats, filled with stones, in the bed or otherwise, for not only would this be a most laborious process in the case of a great river, but the water, if obstructed at one point, would soón force for itself a channel elsewhere, and this new channel would be available for navigation. No doubt railways will carry troops 
more rapidly than steam-vessels on the rivers can do, but the question is, whether it is ndvisable to purclase this superior speed at so enormous a cost, especially when it is notorious that the more rapid expedient of communication may fail us altogether precisely at the moment at which its services are most required.

These are the considerations which have led me to the conclusion that, in seeking to amend the internal communications of India, it is with the more effectial navigation of the rivers by steam that the improvement should begin. The rivers should be made the base of our operations, and, after we have ascended the various branches of the rivers as far as we can do by the most suitable species of vessel that we can employ for the purpose, we must thenceforward continue the communication by a canal, by a road, or by a railway. The particular expedient which should be selected must depend upon the special features of each particular case, but, where a canal can be used, it will in general be the best, as it may be used for the purposes of irrigation, and its ramifications will collect the produce of the country almost from every field. Conveyance by canal is well known to be cheaper than conveyance by railway, and in India, where the canals may be made profitable from the irrigation alone, it is not necessary that any charges whatever for their navigation should be made.

Notwithstanding the advantages of canals, however, there are many situations in which they cannot be advantageously introduced, and there the proper course will in general be to construct a good common road, which in course of time may be transformed into a railway. In some cases, however, it will be advisable to introduce a railway at once without this preliminary preparation; but, as. a railway is a more expensive instrument of communication than a rond, it will be proper if there is not already a considerable trafic in the district to begin with a road, so that the traffic may grow and ripen to such an extent as to warrant the introduction of a railway. Most of the railways hitherto constructed in India are much too expensive. The traffic will be only the same whether you make a cheap railwiy or a dear one, and you may make a very cheap railway if you are content with a moderate rate of speed. Some of the American lines lave been made at a cost of $£ 1$;:600 per mile. 
On the Indian lines by far the larger part of the reveuue is derived from thipd-class passengers, whom it is not necessary to carry at a high rateiof speed. On the East Indian, and also on the Bombay Line, for eyery first-class passenger carried there are about seyenty third-class. It is only to first-class passengers that high rates of specd can be supposed to be of very much value, and in India firstclass passengers are too few in number to be worth much con.sideration in dealing with the question of the railway finances. I think that whatever railways are made in India should not only be of a cheap construction, but slould follow such routes as to escape the competition of navigable rivers and canals, both because it is a breach of economy and a waste of effort to call into existence duplicate lines of communication when the field is so vide, and there is so much to be accomplished, and because, in any competition which a railway, espeçially if of a costly chiracter, eạn carry on with a fiver which costs nothing to make or to maintain, or with an irrrigating canal which, with all its ultimate ramifications, may be navigated without expense, the railway must, in the cheap conveyance of all those inexpensiye articles of produce which constitute the bullk of the traffic of the country, be necessarily outdone.

In a letter which I addresssed to the President of the Board of Control, in 1856, on the subject of public works in India, I recapitulated the cost of conyeyance by railwiys, by rivers, and by canalis in America, and the experience acquired in that country as to the relative cost of different methods of locomotion is in conformity with that acquired in other parts of the world, and all goes to show that water-conveyance is the cheapest of any.

Notwithstanding the existence of numprous railways in the state of New York, the canals have increased in number, and the Erie Canal lias been doubled in vidth for the accommodation of the traffic, The tonnage of ten of the chief railways of that state varies from two per cent. to fourteen per cent. of the tonnage of the Errie Canal, and the total tonnage of these ten railways is yery little more than half the tonnage of the Erie Canal. In other Fords, there is about twenty times the traffic upon each mile of this canal that there is upon each mile of the railways. In Americe the demand for rapid locomotion is mucl more exigent than it can 
be in India for many years to come, and, as every member of the community in Americe has more money to spend, he can better afford to indulge in the luxury of costly, or gomparatively costly, means of communication. If therefore in America water conveyance subserves such important ends, and if it has been found advisable to construct such railways as are made in the cheapest possible manner, much more conspicuously will these conditions hold in the case of India, which is in a much more primitive state, and where almost everything has yet to be done. The problem which has to be solved in the case of India is, how to do most good with the least money. Cheap, simple, and inexpensive improvements widely scattcred over India are wanted in that country, rather than certain superfine methods of locomotion restricted to a narrow area, and of so expensive a character as to be incapable of returning a satisfactory profit. It so happens that in America the error was committed, on the first introduction of railways into that country, of following the example set by railway companies in England. But this plan had to be abandoned, as the engineer of the State of New York naïrely remarks, "because capital could not be obtained, and roads thus constructed were not remunerative." Because America however had the misfortune to run into this error, and thus swell the average cost of her railways beyond a proper amount, are we therefore to run into precisely the same error in the case of India, and then plead the example of America as an apology for the indiscretion? $\Lambda$ ligher class of railway moreover is required for a large part of the United States than is nccessary for Indin; and, finally, Jabour is much cherper in Indin than in the United States, so that the same quality of railway should be obtainable in India at a lower cost.

From these and other considerations which might bo mentioned, I think it impossible to doubt that the railways heretofore constructed in India have been made in too expensive a manner. They lave also in many cases, in my opinion, started from improper points, and have been carried in some instances in improper directions. Thus the East Indian Railway runs from Calcutta to Delli or Meerut, a distance of about 900 miles, on the banks of the Ganges and the Jumna. It ought, in my opinion, to have rather begun 
where those rivers ceased to be navigable. The line from Mirzapore towards Jubbulpore, which is proposed to be constructed by the East Indian Railway Company, appears to me to be judiciously sclected, and if this line is cheaply constructed I have no doubt that it will pay well. The Scinde Railway, which is to run from Kurrachee to a place called Fotree upon the Indus, ought to have been a camal, as it was first intended to be, for it is not to be expected that boats descending the Indus with merchandise or produce for Kurrachee will unload their cargoes at Kotree, so that they may be transported by railway to Kurrachee, when the boats, by descending the river a little lower, will carry their cargoes to Kurrachee without the necessity of any transhipment at all. The Punjaub Railway is to run from Moultan and Lahore, and it will have the river Ravee upon the one side of it and the river Sutlej upon the other side. 'The Ravee is a tortuous river and the Sutlej is a shallow one at certain sersons ; but both rivers are quite capable of being navigated by steam-ressels of the same character as that represented in the plate. The Enstem of Bengal Railway is to run from Calcutta to the Ganges at Koostree, near Pulna (130 miles), being the first section of a line to Dacea. The Madras Railway Company is to carry a line from Madras to Beypore, on the western coast, 430 miles, and from Madras, riî Cuddapah and Bellary, to meet a line from Bombay at or near the river Kistna, $\mathbf{3 1 0}$ miles. The Mradras line has been constructed at a cheaper ate than the other railways, a distinction which is probably mainly imputable to the circumstance that General Sim, who is the chairman of the railvay, was formerly the chief engineer of Madras, and he knew the ground, knew in what manner the work should be carried on to attain the most economical result, and knew that expensive construction was altogether inadvisable The lines of the Great Indian Peninsula Company have their commencement at Bombay, and on: line is to be carried from thence in a sonth-east direction, viâ Poonah and Sholahpore, to the Kistna river, 357 miles, to meet the line fiom-Madras; and another line is to be carried north-east from Bombay to Jubbulpore, 818 miles, to meet the line from Mirzapore. 'The Bombay, Baroda, and Central India Railway is to lead from Bombay to Surat, Baroda, and Ahmedabad, 330 miles. Even if these railways can be made at 
the estimated cost of $£ 34,000,000$, which is doubtful, a vast deal will still remain to be done to set the internal communications of India upon a satisfactory basis. The railways will be comparatively inaccessible until roads leading to them are made, and even when all this is done they will be unable to compete with the rivers in carrying the produce of the country through long distances at a cheap rate. Thus if we suppose that wheat, or linseed, or timber, or any other ordinary agricultural produce, has to be brought from a point at the upper terminus of the East Indian Railway to Calcutta, the cost of transport, even at the very low rate of one penny per ton per inile, will be $£ 3$ 15s. per ton. By the river the same commodities could be conveyed with profit for one-third of the amount. Seeing, however, that the railways are an established fact, it is highly desirable that we should utilise them as far as possible by opening up roads to them of a cheap kind, but widely ramifying, and by the adoption of all such measures as without occasioning any heavy expense appear calculated to swell the traffic. The measure however in which $I$ have the most faith is the introduction of such other improvements as will bring the country up to that pitch of wealth and prosperity which will enable the people to pay for the use of expensive railways. This is only to be done on any extensive scale by adding to the fertility of the soil by establishing works of irrigation, the distributing channels of which will enable the increased produce of the soil to be carried to the rivers, and by them to the sea, at a very small expense, and we shall thus not only receive from India large supplies of the cotton, sugar, rice, wool, wheat, flas, and other articles which we require in this country, transmitting our manufactures in return, but we shall add so rapidly to the wealth of the people as to raise them speedily to that social status which will enable then to use railways of that expensive character which are suited to more wealthy countries.

These then constitute the main topics connected with the internal communications of India which I wish to submit to your consideration, and which in conclusion I may briefly recapitulate. It is equally the interest of a nation as of au individual to get the largest benefit possible from the money it expends, and I have shown that by introducing steam-ressels of a suitible character upon the rivers 
about 10,000 miles of steam highways may be acquired without any expense. This, as the cheapest expedient of improvement, and the most prompt in its realization of advantage, ought to have been the first of whith the government availed itself. But it is not merely the cheapest, but is in some respects the best for the undereloped circumstances of India, since it enables communication to be carried on at less expense than is possible in the case of railways, and which with roads and canals of irrigation and navigation would yield a large return to the persons embarking their money in them, would add greatly to the productiveness of the country, and, by enabling the increased yield of produce to reach with ease a remunerative market by descending the rivers to the sea, would increase the revenue, and augment the comfort and happiness of the pcople.

Two Models were then exhibited to illustrate the process of lowering boats at sea: one the invention of Mr. Russell; the other the invention of MIr. Clifford.

The invention of Mr. Russell, which was explained to the Meeting by Mr. LoFT, consists of three things:

1st. Of an apparatus or winch for hoisting up the boats (fig. 4), and also of a friction-band or brake for lowering the boat after it has been hoisted up. In the model this apparatus is fitted outside the sponsons (of a steam-vessel); but Mr. Loft explained, that it can be plact flush with the stanchions inside the bulwark, and that it may also answer for the purpose of shipping and unshipping goods from the hold when the vessel is in harbour, for which purpose it was used in the Crimen.

2ndly. Of a rod which passes between the keel and keelson plank of the boat (fig. 5), and which being connected with the apparatus alike.at the stem and the stern, $a$ man in the boat by means of a lever (amidships) can instantly disengage her.

3rdly, of a davit, fitted in two pieces (figs. $1,2,3,4$ ); the upper ends being connected together by means of a chain, and the lower end of the one piece united to the other by means of $n$ hinge; consequently, in lowering, the upper end of the one part of the davit falls 

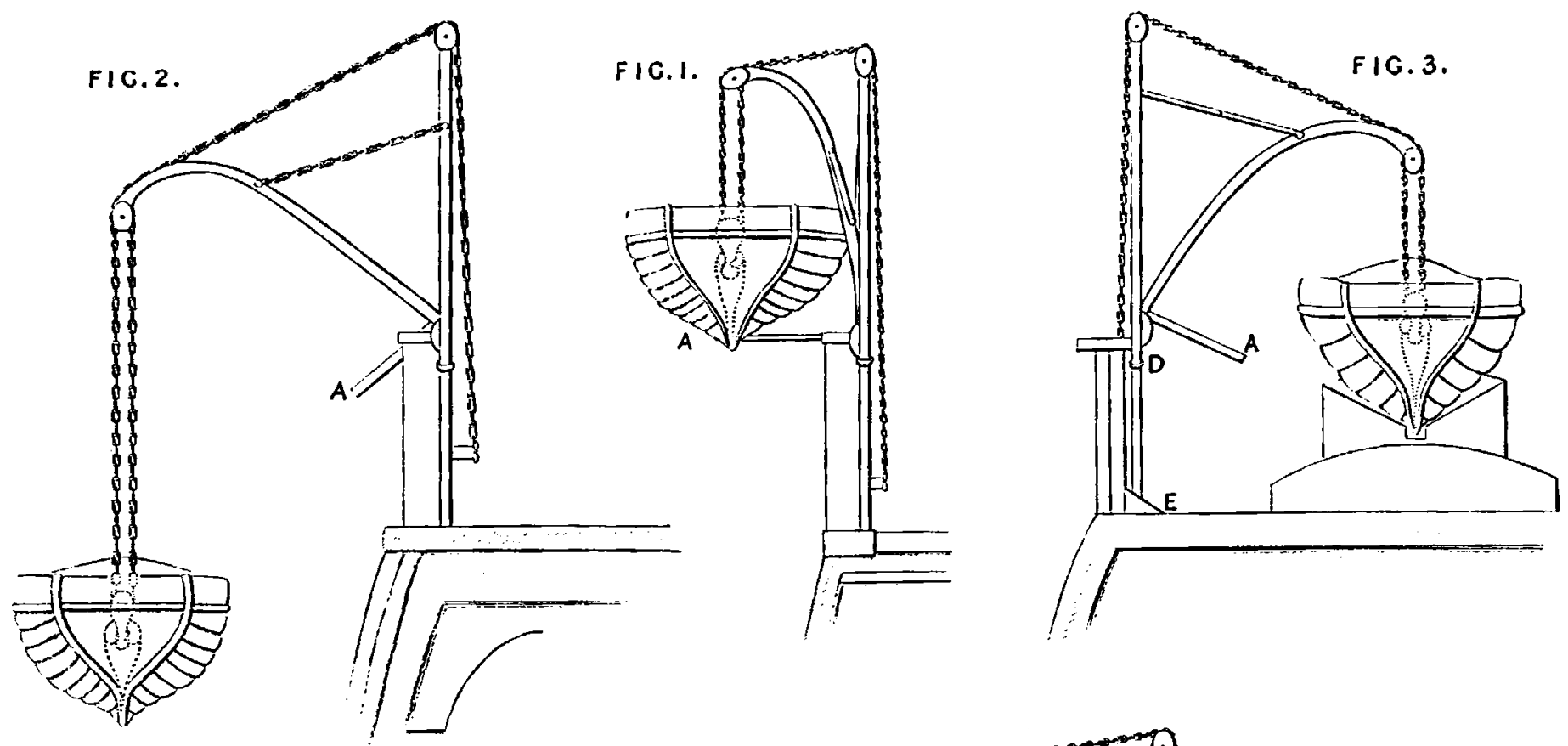

FIG. 4.
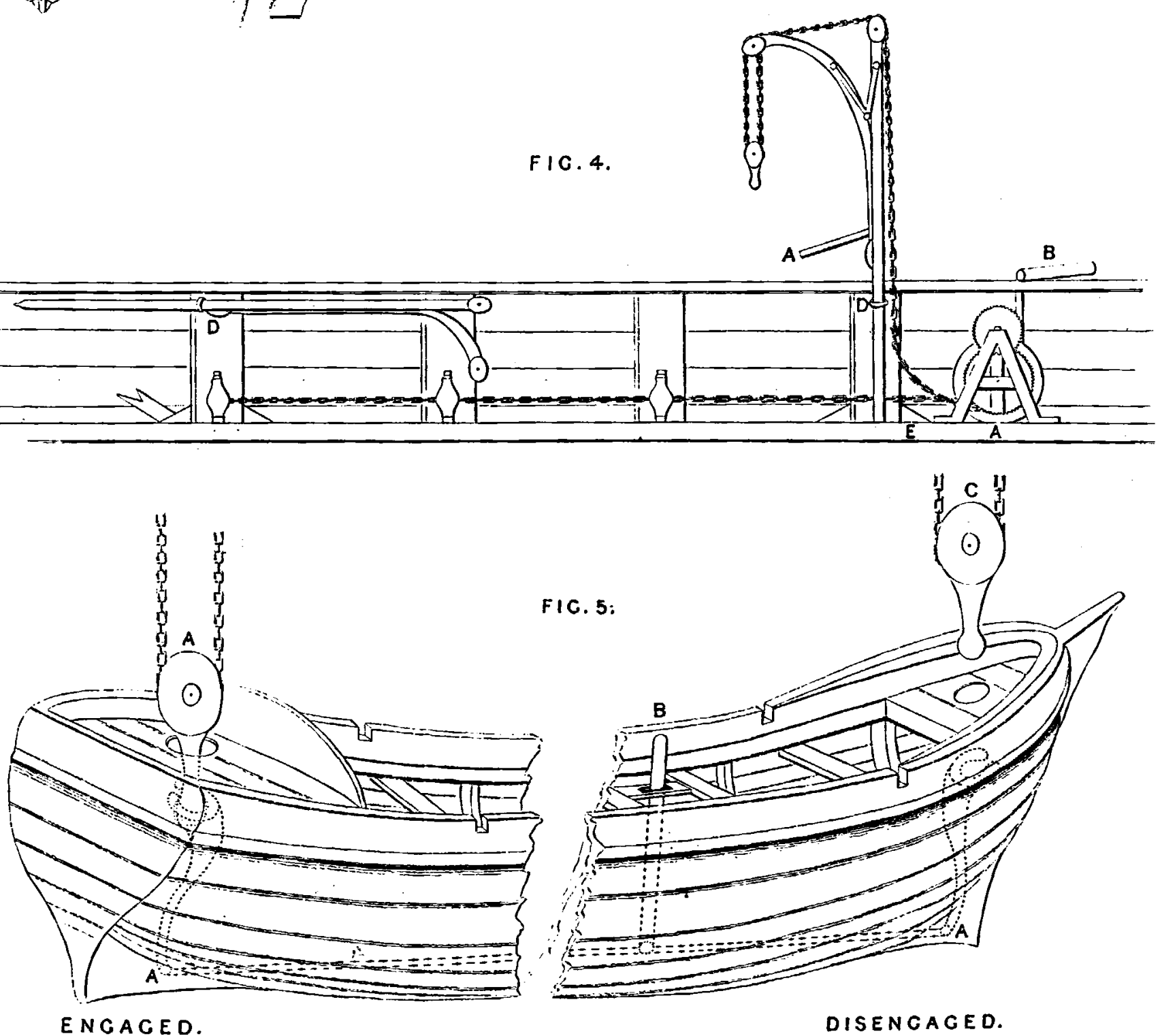

ENCACED.

DISENCAGED.

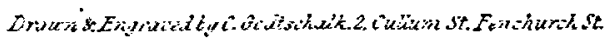


clear of the other to the extent of the chinin comnceting them, and thus far the boat is lowered clear of the side of the ship.

In the discussion which ensued, Mr. STIRLixa Lacos stated that, although the Institution desired to give every encouragement to the exhibition of inventions, and although the Members as a body abstained from any expression of opinion, yet as an individual he could not refrain from expressing his own feelings on the subject, the object of these meetings being to court the expression of opinion on the part of individual Members, and thereby, if possible, to elicit the truth. The present plan professed both to louer and to hoist boats by the same machinery. Without going into the merits of the whole question, he did not believe that any plan of lowering boats would be received with favour by the Naval Service which sought to do awny with the present system of hoisting by the tackles. $\Lambda$ model of Mr. Clifford's system was before them; he considered it too valuable to introduce to their notice at that late period of the evening, but he lroped that the Chairman would so arrange that at some early period the principles which were illustrated by $\mathrm{Mr}$. Glifford's system might be explained to the Institution.*

Admiral Sin George Surmonius stated that the contrivance of Mr. Clifford was very ingenious; the great point in cases of this kind was to lower the boat, and not to hoist it up; that was the great danger.

The Chamus was sure that this Mecting was much obliged to Mr. Loft for explaining his model as he had done; on another occasion, perhaps in the course of a month, the subject might be gone into as a whole, when the MIembers would be glad if Mr. Clifford would also explain his invention.

* Mr. Clifford's mode of lowering boats forms the subject of a lecture, and will appear in a subsequent number. 